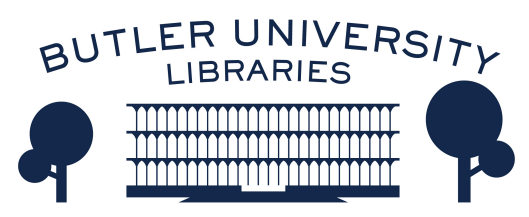

Journal of Hindu-Christian Studies

Volume 23

Article 11

January 2010

\title{
Viewpoint: What I See: Little Indias, Caste, and the Church in the West
}

Rachel Fell McDermott

Follow this and additional works at: https://digitalcommons.butler.edu/jhcs

Part of the Religion Commons

\section{Recommended Citation}

McDermott, Rachel Fell (2010) "Viewpoint: What I See: Little Indias, Caste, and the Church in the West," Journal of Hindu-Christian Studies: Vol. 23, Article 11.

Available at: https://doi.org/10.7825/2164-6279.1463

The Journal of Hindu-Christian Studies is a publication of the Society for Hindu-Christian Studies. The digital version is made available by Digital Commons @ Butler University. For questions about the Journal or the Society, please contact cbauman@butler.edu. For more information about Digital Commons @ Butler University, please contact digitalscholarship@butler.edu. 


\title{
VIEWPOINT \\ What I See: \\ Little Indias, Caste, and the Church in the West
}

\author{
Rachel Fell McDermott \\ Barnard College
}

RECENTLY a New York Times article, "From Untouchable to Businesswoman" (July 22, 2010), carried the story of Kakuben Lalabhai Parmar, an illiterate Scheduled Caste woman from Gujarat who was selling her patchwork embroideries at New York's posh Asia Society. Thanks to intervention in India twenty years ago from SEWA, the Self-Employed Women's Association, she came out of seclusion in her house to participate in society, while helping to preserve the traditional handicrafts : of her village. The result is a globe-trotting artisanbusinesswoman who exchanges hugs with her clients, buys shampoos at CVS for her daughters back home in the village, and seems at ease in new environments.

Such stories are heart-warming, and demonstrate the benefits to individuals of an increasingly open Indian economy, global feminism, the social work of NGOs, the erosion of caste consciousness in certain urban and transnational contexts, and the influence in the United States of an affluent India lobby that sponsors the importation of Indian art from overseas. But one wonders how Ms. Parmar would fare if she settled in New York -- perhaps in the large South Asian community in Queens - and tried to enter American society. After being lionized by the well-to-do in museums and cloth emporia, would she find acceptance in local Indian communities, and would her caste be as invisible in those communities as it is in the non-South-Asian contexts of her business transactions?

I have been newly sensitized to caste in American settings through my research, since 2006, on Dalit Christians in the New York New Jersey area. What I have found is that Dalit Christians in this country have managed in many ways to move away from the stigma of caste; they emigrate as highly trained nurses, doctors, hospital administrators, teachers, and pastors, often through training received in India in church-affiliated educational and healthrelated institutions. Once here, in the United States, their standard of living and expertise often mask the pain and social hindrances of their caste backgrounds. They can "hide," as my Dalit Christian priest friend, the Rev. Gideon Jebamani, characterized the phenomenon of Dalit diaspora living. However, caste still abounds in the church, in both Indian and American settings, as I began to see when trained to look for it.

Many denominational groups, especially those from the upper-caste South India Syrian traditions, have created "enclave" churches here, whose ecclesiological ties are to Indian bishops, whose services are conducted in their home vernacular, in many cases Malayalam, and whose liturgical traditions are borrowed directly from India. As Father Gideon said to me, "there is no question of my being welcomed in such a church." Dalit Christians have several other

Rachel Fell McDermott is Anne Whitney Olin Professor of Asian and Middle Eastern Cultures, Barnard College. Her interests and publications center on goddess worship in Bengal, Hindu-Christian comparative theology, and Indian Christianity in the West. A book on the annual festivals to the goddesses of Bengal is due out in spring 2011, and she is the Managing Editor for the two-volume third edition of The Sources of Indian Tradition, currently in process. Her newest project focuses on the national poet of Bangladesh. Kazi Nazrul Islam. 
options: to join mainstream "American" ("white," "black," or Hispanic) churches, where fellow congregants are ignorant of caste and where the Dalit family is just "Indian"; to attend all-Dalit churches, where social acceptance is assured within the walls of the church; or to take membership in churches that are led by Indian priests or pastors with the expressed hope of providing spaces for Christians of mixed background to experiment with mutual acceptance and diversity. Some Indian Christians combine their worship commitments, attending or leading a "mainstream" church in the morning and finding fellowship with Indians in a different worship context in the afternoon or evening.

A recent trend among a few visionary priests is to meld enclave and mixed-background Indian churches with mainstream (usually white) ones, especially in places where the mainstream church is dying. The Rt. Rev, George Ninan, in Valley Cottage, NY, and the Rev. Jacob David, in Wood-Ridge, NJ, are both leading combined churches; in addition, Bishop Ninan has founded the Christian Institute for South Asiamerican Concerns, in an effort to encourage Indian Christians to participate fully in mainstream American life, to "own" the United States, as it were, as a site itself for mission, dialogue, and outreach. Although the members of these churches and of the CISAC are not primarily Dalit, this integrative move does provide space, philosophically and physically, for Dalit Christians.

Indeed, the possibilities for change and for the lessening of caste consciousness are many in this country. The late Rev. David Purushottaman, a Dalit whose grandfather converted to Christianity, told me a very moving story in 2007 about how an American setting can provide hope for Dalit Christians. When he first came to this country in the 1980s he vigorously protested against the building of a new Hindu temple near his house in New Jersey. He even testified in a public hearing, asking the Hindu claimants in front of the judge, "how many Christian villages have you burned down? How many Christian missionaries have you chased away?" He was successful in quashing the request. Twenty years later, however, in
2003, a different Hindu temple was built in his area. To his surprise, he was invited as a guest. At first he thought that the Hindus had been misled by his Hindu-sounding last name, but they said, "no, we want you to come and bless us." "But I can only bless you in the name of Jesus," he said. "Fine," they responded, "that is what we want." "They seated me on a dais," he told me, and then lowered his voice to a whisper, "right next to the Brahman priest....I could never have imagined this."

And yet, in further conversations with him, as with every other one of my Dalit Christian friends and conversation partners, I learned that the stigma of Dalitness is hard to wash off, even here. Indians in mixed-caste congregations may not accept invitations to Dalit Christian houses. They may be reluctant to allow their children to intermarry. One Dalit priest confided his caste background in me but implored me never to mention it to his mixed-background congregation, lest the non-Dalits leave. Some live with this doubleness by becoming Dalit activists, eschewing the attempt to "hide" or to "pass," while others feel that the solution is the quiet attempt to blend, even if this does entail a certain covering up of identity. "Caste, color, and culture: these are the first things we pack in our suitcases," said Rev. Purushottaman wryly.

In Princeton in 2007, at a meeting of local Indian church leaders who had met to discuss the best means of seeding Indian Christianity in American contexts, one speaker boldly spoke of caste as the "elephant in the room." Only two people publically disagreed; most looked uncomfortable and remained silent. I thought of this comment again a few months later, when a perspicacious young Dalit woman told me something that chills me, and that I do not know how to evaluate. She said that as long as South Asian communities in this or any other diasporic setting continue to grow and expand, with "little Indias" forming and associations being founded to address the needs of immigrant families or to foster the creation of pride in the second and third generations, caste consciousness will flourish. It is inherent to the process of identitycreation to erect boundaries, she said, to make insiders and outsiders. Low-caste people will inevitably be the "others" in a mixed group that 
looks to India or Indian culture as its defining standard.

Until this conversation, I had always thought positively, as a sign of the community's maturity, of Indian neighborhoods and Indianmajority towns, even, as places where culture could flourish and where religious practices, in particular, could evolve in conversation with "authentic"- traditions in India. But now I see that the other side of community cohesion, made possible through constant incoming waves of immigrants, is a potential for the importation of hardening social prejudice. In other words, a diaspora Dalit probably has a better chance of escaping the woundedness of caste if he or she lives in a non-Indian neighborhood or, like Ms. Parmar, makes infrequent visits and then interacts chiefly with a speciality audience.

But herein lies the rub. The fear of caste prejudice is not, and perhaps should not be, strong enough to undercut all the other benefits to enclave living, like the reinforcements of Indian language learning, cuisine, music, clothes, art, and religion, not to mention friendships that can be fostered among people "from back home." The challenge, then, is for
Indian communities to lessen and loosen caste stereotypes, as happened to the Rev. Purushottaman in 2003, and to encourage integrative efforts such as those of Revs. Ninan and Jacob.

It is my strong feeling that the oppression of being Dalit is not merely an Indian issue or a Hindu one; it is live and presses upon us in Indian communities -- Hindu, Sikh, and Christian -- here, in the United States, in our own neighborhoods. Soothing away the "untold pain" of being a Dalit, which Fr. Gideon worries, even now, prevents him from truly expressing Christian joy, will require determination, activism, time, change in India, and an inner dialogue between old and new immigrant communities concerning the core of Indian-American identity. Will there come a time when caste is irrelevant in Indian Christian contexts in the United States? Does the elephant have to be recognized before it can be shown the door? And who will escort it out, and from what kind of community? These are questions easily overlooked, because the communities concerned rarely press them, for fear, but I believe them to be urgent. 